\title{
A requiem for North American overkill
}

\author{
Donald K. Grayson ${ }^{\mathrm{a}, *}$, David J. Meltzer ${ }^{\mathrm{b}}$ \\ ${ }^{a}$ Department of Anthropology, Box 353100, University of Washington, Seattle, WA 98195, USA \\ ${ }^{\mathrm{b}}$ Department of Anthropology, Southern Methodist University, Dallas, TX 75275, USA
}

Received 8 March 2002; revised 1 June 2002; accepted 13 June 2002

\begin{abstract}
The argument that human hunters were responsible for the extinction of a wide variety of large Pleistocene mammals emerged in western Europe during the 1860s, alongside the recognition that people had coexisted with those mammals. Today, the overkill position is rejected for western Europe but lives on in Australia and North America. The survival of this hypothesis is due almost entirely to Paul Martin, the architect of the first detailed version of it. In North America, archaeologists and paleontologists whose work focuses on the late Pleistocene routinely reject Martin's position for two prime reasons: there is virtually no evidence that supports it, and there is a remarkably broad set of evidence that strongly suggests that it is wrong. In response, Martin asserts that the overkill model predicts a lack of supporting evidence, thus turning the absence of empirical support into support for his beliefs. We suggest that this feature of the overkill position removes the hypothesis from the realm of science and places it squarely in the realm of faith. One may or may not believe in the overkill position, but one should not confuse it with a scientific hypothesis about the nature of the North American past.
\end{abstract}

(C) 2003 Elsevier Science Ltd. All rights reserved.

Keywords: Extinction; Pleistocene extinctions; Pleistocene overkill; Mammoth; Mastodon; Clovis; North America

\section{Introduction}

Toward the end of the Pleistocene, some 35 genera of primarily large mammals became extinct in North America, either in the sense that they no longer exist anywhere in the world (29 genera), or that they ceased to exist here while living on elsewhere (six genera; see Table 1). More than 40 years ago, Paul S. Martin began to develop what has become the most visible explanation for these losses: the extinctions, he argues, were due entirely to the impacts of human hunting $[52-57,59,60,65,72]$.

Few speculations about the prehistoric past have achieved as much celebrity as this one. Hardly a textbook or popular scientific treatment of New World archaeology, ecology, and environmental history misses the opportunity to discuss it, with many understandably keen to use this apparent illustration of human destructiveness to teach a well-intentioned lesson in

\footnotetext{
* Corresponding author. Tel.: +1-206-543-5240; fax: +1-206-543-3285

E-mail address: grayson@u.washington.edu (D.K. Grayson).
}

conservation. Yet despite this popularity, Martin's position gains virtually no support from the North American late Pleistocene archaeological and paleontological records. As a result, it gains almost no support from the scientists who specialize in these records. Here, we provide a brief historical background to Martin's argument, and then turn to the empirical record that shows it to be incorrect.

\section{The heart of the argument}

In developing what has become known as the 'overkill hypothesis', Martin was tackling a problem that has intrigued scholars ever since the former existence of such now-extinct mammals as mammoth and ground sloths became known, a process of recognition that began as the 18th century came to an end. Martin's particular approach to explaining the extinctions, however, became popular only after 1860 , the year it was demonstrated in Europe that people had walked the earth with such beasts as the woolly rhinoceros, woolly mammoth, and 'Irish elk' [29,32]. Soon after that acceptance occurred, it 
Table 1

The extinct late Pleistocene mammals of North America

\begin{tabular}{|c|c|c|}
\hline Order and family & Genus & Common name \\
\hline \multicolumn{3}{|l|}{ Xenarthra } \\
\hline Pampatheriidae & $\begin{array}{l}\text { Pampatherium } \\
\text { Holmesina }\end{array}$ & $\begin{array}{l}\text { Southern pampathere } \\
\text { Northern pampathere }\end{array}$ \\
\hline Glyptodontidae & Glyptotherium & Simpson's glyptodont \\
\hline Megalonychidae & Megalonyx & Jefferson's ground sloth \\
\hline \multirow[t]{2}{*}{ Megatheriidae } & Eremotherium & Rusconi's ground sloth \\
\hline & Nothrotheriops & Shasta ground sloth \\
\hline Mylodontidae & Glossotherium & Harlan's ground sloth \\
\hline \multicolumn{3}{|l|}{ Carnivora } \\
\hline Mustelidae & Brachyprotoma & Short-faced skunk \\
\hline Canidae & Cuon $^{\mathrm{a}}$ & Dhole \\
\hline \multirow[t]{2}{*}{ Ursidae } & Tremarctos ${ }^{\mathrm{a}}$ & Florida cave bear \\
\hline & Arctodus & Giant short-faced bear \\
\hline \multirow[t]{3}{*}{ Felidae } & Smilodon & Sabertooth \\
\hline & Homotherium & Scimitar cat \\
\hline & Miracinonyx & American cheetah \\
\hline \multicolumn{3}{|l|}{ Rodentia } \\
\hline Castoridae & Castoroides & Giant beaver \\
\hline \multirow[t]{2}{*}{ Hydrochoeridae } & Hydrochoeris $^{\mathrm{a}}$ & Holmes's capybara \\
\hline & Neochoerus & Pinckney's capybara \\
\hline \multicolumn{3}{|l|}{ Lagomorpha } \\
\hline Leporidae & Aztlanolagus & Aztlan rabbit \\
\hline \multicolumn{3}{|l|}{ Perissodactyla } \\
\hline Equidae & Equus $^{\mathrm{a}}$ & Horses \\
\hline Tapiridae & Tapirus $^{\mathrm{a}}$ & Tapirs \\
\hline \multicolumn{3}{|l|}{ Artiodactyla } \\
\hline \multirow[t]{2}{*}{ Tayassuidae } & Mylohyus & Long-nosed peccary \\
\hline & Platygonus & Flat-headed peccary \\
\hline \multirow[t]{3}{*}{ Camelidae } & Camelops & Yesterday's camel \\
\hline & Hemiauchenia & Large-headed llama \\
\hline & Palaeolama & Stout-legged llama \\
\hline \multirow[t]{2}{*}{ Cervidae } & Navahoceros & Mountain deer \\
\hline & Cervalces & Stag-moose \\
\hline \multirow[t]{3}{*}{ Antilocapridae } & Capromeryx & Diminutive pronghorn \\
\hline & Tetrameryx & Shuler's pronghorn \\
\hline & Stockoceros & Pronghorns \\
\hline \multirow[t]{3}{*}{ Bovidae } & Saiga $a^{\mathrm{a}}$ & Saiga \\
\hline & Euceratherium & Shrub ox \\
\hline & Bootherium & Harlan's musk-ox \\
\hline \multicolumn{3}{|l|}{ Proboscidea } \\
\hline Mammutidae & Mammut & American mastodon \\
\hline Elephantidae & Mammuthus & Mammoths \\
\hline
\end{tabular}

${ }^{\text {a }}$ Genus survives outside of North America.

became so routine to attribute European extinctions to human hunting that, by 1872 , this argument was being referred to as 'the favorite hypothesis' [90, p. 155].

While the intellectual roots of the overkill approach to explaining Pleistocene extinctions lie in 19th-century western Europe, our current understanding of the archaeology, vertebrate paleontology, and late Pleistocene climate history of that region is such as to leave the hypothesis no strong adherents there. Instead, it lives on elsewhere, most notably in Australia and North America. The situation in Australia is in considerable flux, and we therefore do not comment on it but instead focus on North America, the area we know best.

In North America, the contemporaneity of humans and extinct Pleistocene mammals was not demonstrated until the early 1930s, at Clovis, NM, where the evidence suggested that people had hunted the animals involved. A series of similar sites were discovered during the decades that followed. That several of those sites on the North American Plains and in the southwest contained the remains of mammoth clearly warranted the inference that Clovis groups at least occasionally hunted this animal. This reasonable observation was then transformed into the generalization that Clovis groups were specialized big-game hunters, even though there was (and is) no evidence for such specialization. Once that had occurred, a number of scholars found it reasonable to attribute North American Pleistocene extinctions at least in part to human hunting $[66,67]$.

The contemporary North American version of the overkill hypothesis is due almost entirely to Martin, who has developed the hypothesis in sufficient detail to make it convincing to many (e.g. Refs. $[3,4,8,12,19-22,77$, $79,88]$ ), although its most vocal adherents are primarily those whose expertise lies outside the place and time period involved. Martin's hypothesis has changed somewhat over the years, but it has always included four major premises [36,37,39]:

1. It has been well established through archaeological and paleontological research that the prehistoric human colonization of islands was followed by often massive vertebrate extinctions.

2. The archaeological phenomenon known as Clovis, marked by well made and distinctive fluted points and well dated to about 11,000 radiocarbon years ago, is extremely likely to have been created by the first peoples to have entered North America south of glacial ice, and represents the first peoples known to have hunted large-mammals in this huge area.

3. Clovis peoples preyed on a diverse variety of now-extinct mammals.

4. The late Pleistocene North American mammal extinctions occurred at or near 11,000 radiocarbon years ago.

From these key premises, Martin concludes that Clovis hunters caused these extinctions. Direct human predation, he argues, removed the herbivore contingent, while the loss of the herbivores led to the extinction of such carnivores as the saber-tooth and scimitar cats and the giant short-faced bear.

As we have noted, the overkill hypothesis was born in 19th-century Europe, only to be rejected as our understanding of western European archaeology, vertebrate paleontology, and climate history became sufficiently well refined to make it clear that the comings and goings of large mammals in this region were tightly linked to 
climate change $[16,18,85,91]$. The North American situation is quite different. Here, the late Pleistocene climate record is strong, but our understanding of the archaeology and paleontology of this period is not. We do, however, know enough to examine Martin's critical premises in detail, and, in doing so, to find his argument significantly wanting.

\subsection{Island extinctions}

To establish that prehistoric humans not only could have caused extinction, but did so on multiple occasions, Martin turns to island settings. There is good reason for this, since it is extremely well documented that on island after island in nearly all parts of the world, prehistoric human colonization was quickly followed by vertebrate extinction (see the review in Ref. [36]).

The most famous example of this phenomenon is certainly provided by New Zealand, where some 11 species of moas - large, flightless birds that ranged in estimated weight from 20 to over $200 \mathrm{~kg}$-succumbed within a few hundred years of permanent human colonization some 900 years ago. All agree that these extinctions resulted from human activities [5,93]. At least 25 other species of smaller vertebrates-lizards, frogs, birds, and at least one species of bat-were lost with the moas, and the list of species lost will surely grow as our knowledge of the recent biotic history of New Zealand grows [36].

While New Zealand may provide the most famous example of human-caused vertebrate extinction in a prehistoric island setting, nearly every island whose archaeology and paleontology is well known illustrates the same phenomenon. In the Mediterranean, only two species of mammals-both shrews-remain of the mammals that were present just prior to the human arrival $[9,87]$. On Mangaia, in the Cook Islands, 13 of 17 species of landbirds known archaeologically did not survive to be described in writing $[47-49,81,83]$. In the West Indies, multiple species of hutias, rodents that had long been present in the region, became extinct after people arrived [71,92]. No matter where we look, as long as terrestrial vertebrates were present, the outcome is the same [36].

In no case is the precise cause or causes of these extinctions known. This is because in all known cases, human colonization was associated with multiple possible impacts on the species that were lost. In New Zealand, for instance, people not only hunted moas, but they also set fires that quickly destroyed massive expanses of forest [62-64] and introduced competitors and predators in the form of rats and dogs $[6,44,45]$. Some combination of hunting, introduced species (including pathogens), and anthropogenic vegetational change caused the losses that are so well documented there. We cannot, however, say what that combination was. The same is true for all known prehistoric, humancaused island extinctions [36]. Because this is the case, none of these extinctions can be securely attributed to hunting alone, although this may certainly have occurred.

The magnitude of prehistoric human-caused vertebrate extinctions on islands came as a surprise when it first began to be described in detail by such scientists as Storrs Olson, Helen James, and David Steadman during the 1980s [73-75,81,84]. Nonetheless, it has long been known that island faunas are in general prone to extinction, and the reasons for this are well understood. Island vertebrates are vulnerable because their populations are small, because they are confined to well-delineated areas of land that may undergo rapid environmental change, because they may have lost (and in some cases have clearly lost) the behavioral mechanisms needed to cope with introduced predators, pathogens, and competitors, and because there is no ready source of conspecific individuals to replenish dwindling populations [11,50, $76,79,82]$. Island faunas are, as Paulay has noted, "among the most vulnerable in the world" [76, p. 134].

Martin's first premise is, then, depressingly true. The initial human colonization of island after island was followed by vertebrate extinction. That this premise is true, however, does not mean that it is relevant to continental extinctions. After all, the factors that make islands prone to vertebrate extinction - small population sizes of resident vertebrates, the lack of a ready source of conspecific colonizers, and so on-do not apply to the continental setting.

What might make some of the lessons learned from the biotic history of islands applicable to the North American setting is evidence that Clovis-aged peoples caused massive environmental disruption of the sort routinely seen in island settings. Of this, however, there is absolutely no evidence [36]. In addition, Martin's hypothesis relies on hunting and hunting alone, and island extinctions resulted not from hunting but from 'the manifold impacts of human colonization', as Holdaway [43, p. 18] has so aptly put it for New Zealand.

\subsection{Clovis first}

Clovis dates to within a few hundred radiocarbon years of either side of 11,000 years ago. Until recently, most archaeologists accepted Clovis as the archaeological manifestation of the first people to have occupied the Americas south of glacial ice. With the recent and fairly general acceptance of the validity of the 12,500-year-old human occupation at the southern Chilean site of Monte Verde, this view has largely crumbled $[23,68,69]$. Given that there is no reason to doubt that people entered the Americas via the Bering Land Bridge, it follows that they must have been in North America long before they 
Table 2

North American archaeological sites with evidence suggesting human predation on now-extinct Pleistocene genera (from Ref. [39])

\begin{tabular}{ll}
\hline Site & Genus \\
\hline Blackwater Draw, NM & Mammoth \\
Colby, WY & Mammoth \\
Dent, CO & Mammoth \\
Domebo, OK & Mammoth \\
Escapule, AZ & Mammoth \\
Hebior, WI & Mammoth \\
Lange/Ferguson, SD & Mammoth \\
Lehner, AZ & Mammoth \\
Lubbock Lake, TX & Mammoth \\
Miami, TX & Mammoth \\
Murray Springs, AZ & Mammoth \\
Naco, AZ & Mammoth \\
Kimmswick, MO & Mastodon \\
Pleasant Lake, MI & Mastodon \\
\hline
\end{tabular}

reached southern South America. Nonetheless, it remains true that Clovis is the earliest well-accepted archaeological phenomenon known from North America. Clovis also provides the earliest secure North American evidence that people did, in fact, encounter now-extinct large mammals.

\subsection{Clovis hunters}

If Martin is correct in blaming Clovis hunters for late Pleistocene mammal extinctions in North America, it would seem to follow that these people must have hunted all of the animals whose extinction they are argued to have caused.

How many of those genera can be shown to have been human prey during Clovis times? The answer is two - mammoth and mastodon-(Table 2) and there are only 14 sites that securely document this relationship [39]. As has long been known [42], this is not a sampling fluke (see Fig. 1). There are more late Pleistocene occurrences of horse than there are of mammoth or mastodon, and nearly as many for camel as for mastodon, yet there are no demonstrable kill sites for horse or camel or for any of the remaining genera $[30,31,34,36,37,39]$. This is not for want of looking. Given the high archaeological visibility of the remains of extinct Pleistocene mammals, and their great interest to archaeologists and Quaternary paleontologists alike, if such sites were out there, they would surely be found. Indeed, there is a strong bias in the Clovis archaeological record toward just such sites $[33,67]$.

The rarity of megafaunal kill sites is such an evident feature of the late Pleistocene archaeological and paleontological records of North America that Martin has had to address it. After all, other parts of the world - Late Pleistocene Europe, for example - are lit- tered with sites that document human predation on large mammals [38].

Martin has attempted to account for the virtual absence of kill sites in an extraordinary way. He argues that it all happened so fast that we should not expect to find empirical evidence of that process. That is, he has been forced to argue that "much evidence of killing or processing of the extinct fauna is not predicted" by his position [56, p. 397]. It is a rare hypothesis that predicts a lack of supporting evidence, but we have one here, and we have it only because evidence for it is, in fact, lacking. Martin argues quite differently for New Zealand, where he calls on the abundance of archaeological sites containing moa remains to bolster his position that human hunting played a role in the extinction of these animals $[56,59]$.

\subsection{The extinctions occurred 11,000 years ago}

Obviously, if Clovis-age hunters caused the extinctions, either directly (the herbivores) or indirectly (the carnivores) of some 35 genera of mammals, those extinctions must have occurred at or soon after Clovis times. However, of the 35 genera involved, only 15 can be shown to have lasted beyond 12,000 years ago [36,37]. This leaves open the possibility that many of the remaining genera became extinct well before Clovis times. In western Europe, late Pleistocene extinctions were scattered in time and space, and there is little in the North American record to suggest that the same thing did not happen here $[18,85]$.

This possibility causes difficulties for the overkill position. Martin and Steadman, for instance, have suggested that the Aztlan rabbit might have been 'large enough' [59, p. 34] to have been hunted to extinction by Clovis-age peoples. This genus, however, cannot be shown to have survived the last glacial maximum some 18,000 years ago. Clovis hunters are thus asserted to have driven the extinction of a very small animal that, as far as we can tell, predated Clovis by at least 7000 years.

But let us assume that as the years go by, more of the mammals will be shown to have become extinct during or soon after Clovis times. How unique would this make the North American extinctions?

The answer is 'not very'. The Northern Hemisphere, in general, saw substantial large mammal extinctions at the end of the Pleistocene (see Fig. 2). In Ireland, the latest radiocarbon date for the giant deer (sometimes called the 'Irish Elk') falls at 10,610 years ago; the latest date for reindeer falls at 10,250 years ago [91]. In southwestern France, reindeer, mammoth, saiga, and the giant deer (among others) disappeared at about the same time that Clovis appeared in North America [18]. In the southern Jura and northern French Alps, reindeer disappeared sometime between 12,000 and 11,000 years ago [10]. In the Taimyr Peninsula of northern Siberia, 


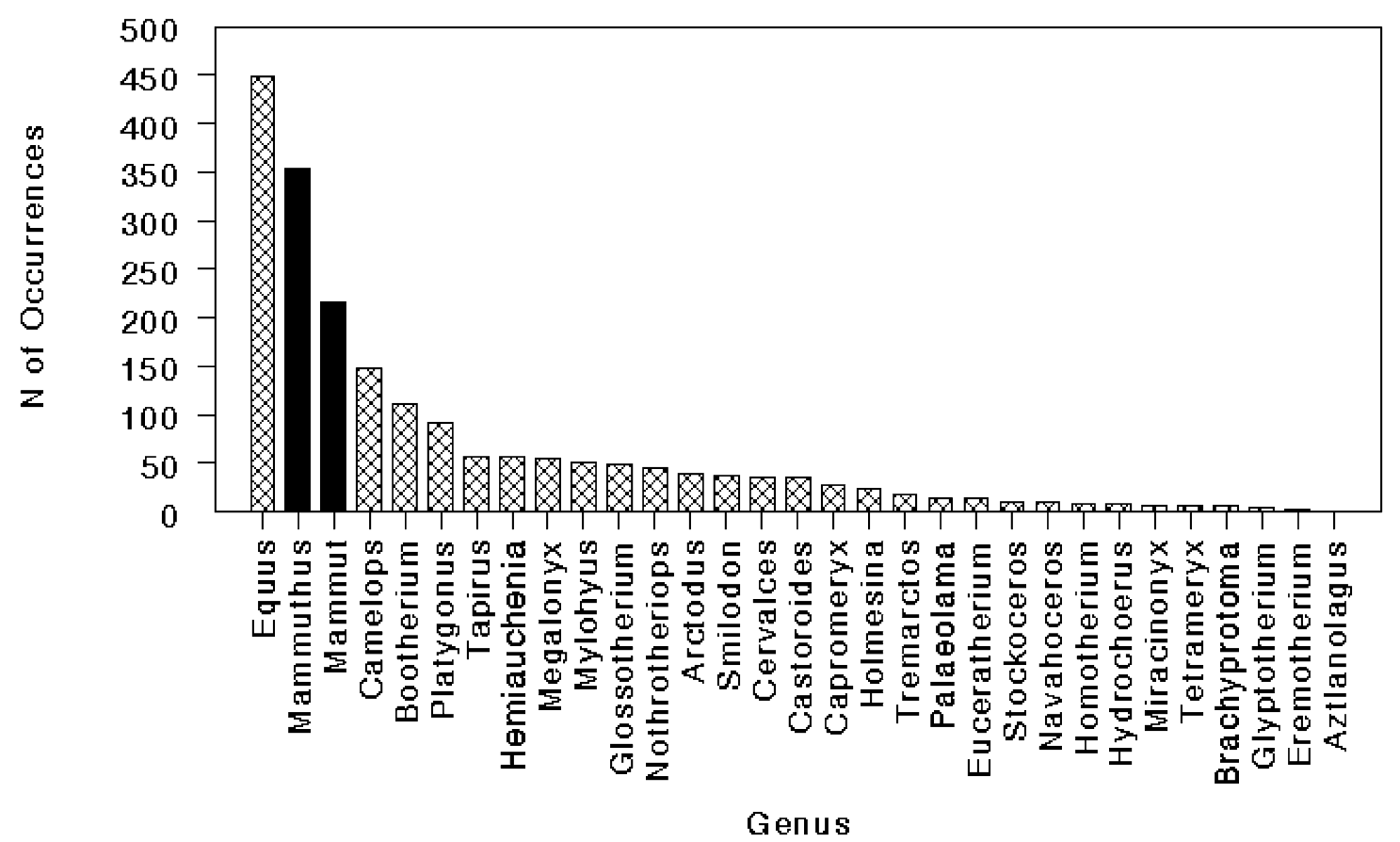

Fig. 1. The late Pleistocene abundances of now-extinct mammals on the North American landscape; solid bars indicate taxa known from kill-site contexts (data from Refs. [26,39]; only taxa in FAUNMAP are graphed here).

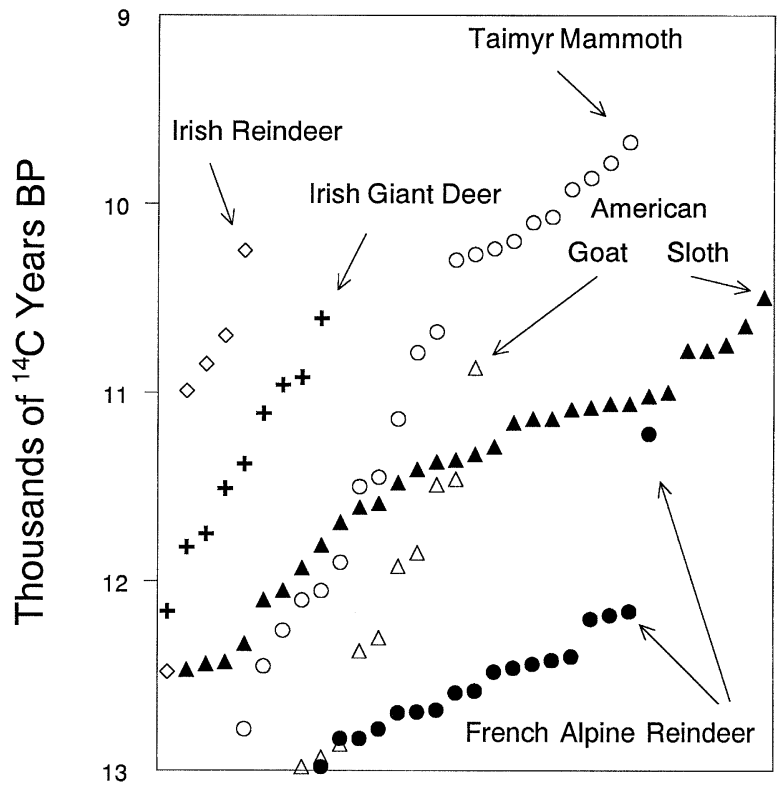

Fig. 2. The distribution of latest Pleistocene radiocarbon ages for selected Northern Hemisphere extinct or extirpated large mammals (see text for references); symbols represent individual radiocarbon age determinations.

mammoth disappeared from the mainland shortly after 10,000 years ago, although they persisted well into the Holocene on Wrangel Island [51]. While all this was happening, Harrington's mountain goat and the Shasta ground sloth disappeared from the American Southwest
[60,65], caribou (North American reindeer) retreat from their late Pleistocene ranges in the American midwest and southeast [14,26,61], and mammoth and mastodon (among others) are lost from the American landscape. Genetic data even suggest that cheetahs in Africa and cougars in North America may have undergone severe population declines as the Pleistocene ended $[17,70]$.

Human hunting had nothing to do with the Eurasian losses. Martin cannot blame human hunters for the disappearance of reindeer and giant deer in Ireland since there were no people in Ireland at the time [91]. In France, reindeer were an important part of the human diet for tens of thousands of years but were not lost until the Pleistocene ended [38]. There were no Clovis hunters in Siberia, yet large mammal extinctions occurred here anyway. Large mammal extinctions occurred at the end of the Pleistocene with or without Clovis, with or without the presence of human predators.

\section{The end of North American overkill}

Martin has recently noted that "archaeologists have always washed their hands of human complicity in large [mammal] extinction" in North America [78, p. 17], and he is right. He might also have added that vertebrate paleontologists who specialize in late Pleistocene North America have also cleansed themselves of this notion $[28,41]$. The reason is straightforward. There is no evidence for it and much against it. While Martin claims that a lack of evidence provides strong support for 
his position, others have different expectations of the empirical record.

Given that archaeologists and paleontologists have washed their hands of North American overkill, who accepts it and what explains its popularity? As we have mentioned, those who praise overkill are, by far and large, scientists who are not familiar with the details of the North American late Pleistocene.

John Alroy is a good example, having published a sophisticated model demonstrating that overkill must have occurred [1]. When questioned about archaeological evidence in support of his model, he points to kill sites for mammoth, mastodon, and the giant tortoise $[2,35]$. As we have discussed, the case for mammoth and mastodon hunting is remarkably limited and that for other large mammals is non-existent [39]. What of the tortoise? Leaving aside the relevance of a tortoise kill for a model of mammalian extinction, the claim that people preyed on the extinct tortoise Geochelone crassicutata is based on the Little Salt Springs, FL, underwater site $[15,46]$. Here, a 'sharply pointed wooden stake' [15, p. 609] was found between the carapace and plastron of an extinct tortoise, and the remains of the animal were said to have been burned. Dunbar and Webb [24] subsequently observed that this material does not appear to be burned at all, and the radiocarbon dates for the wooden stake $(12,030 \pm 200)$ and the tortoise $(13,450 \pm 190)$ are 1400 years apart [15]. Clearly, there is little reason to think that this tortoise was a victim of human predation.

Alroy accounts for the general lack of kill sites for the extinct mammals by noting that "smaller species are not expected because smaller bones are fragile, and so skeletons of smaller taxa are preserved only rarely outside of kill-free natural trap environments" [2, p. 1460]. We leave it to the reader to decide whether musk-oxen, camels, horses, and giant ground sloths had small and fragile bones, but we do observe that scores of Pleistocene archaeological and paleontological sites in Europe are full of the remains of such 'fragile' animals as horse, bison, and reindeer.

Quantitative models like Alroy's are, of course, commonly brought to bear on questions of past climate and environment. However, those quantitative models are routinely evaluated (and then adjusted and refined) by carefully comparing model results with relevant empirical data [80,89]. Attempts to explain North American terminal Pleistocene extinctions should not be exempt from the same approach.

Our point is simple. The North American version of the overkill hypothesis lives on not because of archaeologists and paleontologists who are expert in the area, but because it keeps getting repeated by those who are not. As to why it remains popular in those circles, there are likely several reasons, but one seems especially compelling.
The first detailed development of the overkill hypothesis came in 1967 [54], the same year that the Environmental Defense Fund was launched [86]. Five years earlier, Rachel Carson's Silent Spring had appeared [13]; a year later, in 1968, Paul Ehrlich produced The Population Bomb [25]. By 1970, the US National Environmental Policy Act had been passed and Earth Day created [7]. We are not suggesting that the overkill argument emerged as an integral part of the environmental movement; after all, Martin first raised the idea a decade earlier, and overkill models emerged in mid-19th century England in a very different historical context. Instead, we suggest that the overkill argument captured the popular imagination during a time of intense concern over our species' destructive behavior toward life on earth. It retains that grasp today.

It is easy to show that overkill's continued popularity is closely related to the political uses to which it can be put. Take, for instance, Peter Ward's recent discussion of the matter. Ward - a superb paleontologist whose scientific research focuses on fossils that are between about 300 million and 60 million years old-is convinced by Martin's arguments, concluding that "the ravages of hungry people surely were involved in the destruction of many species now extinct" [88, p. 223]. In this conclusion, he finds "tragic validity for times approaching": "the Snake River salmon is virtually extinct ... king crab fishing in Alaska has been essentially terminated because the stocks are gone; the great shellfish fisheries of Puget Sound have been halted because the oysters and mussels are too poisoned by industrial wastes to eat" [88, p. 227]. For Ward, the overkill position is inextricably linked to modern times and to the homily of ecological ruin.

Ward is not alone in taking this approach. In The Third Chimpanzee, ecologist Jared Diamond enthuses over Martin's argument and ends the chapter with a brief discussion of "the blitzkriegs by which modern European hunters nearly exterminated bison, whales, seals, and many other large animals". The next chapter begins with a discussion of "the risk of a nuclear holocaust" [22, pp. 347-348].

For these discussions, and others like them, overkill provides powerful political capital. That we may agree with the political goals of these authors is immaterial. Our concern here is that both science and environmental concerns are being done a disservice by relying on claims that have virtually no empirical support. We are not suggesting that those who use overkill in this way do so in disregard of the facts against it. We do believe, however, that they are insufficiently familiar with the archaeological and paleontological records bearing on overkill, and so cannot properly judge Martin's claims of its explanatory power.

In fact, Martin's recent writings suggest to us that he is no longer trying to approach this issue within a 
scientific framework. As we have noted, he explicitly maintains that the North American overkill position does not require supporting evidence. He is unconcerned that archaeologists 'wash their hands' of his ideas. He criticizes the search for pre-Clovis sites in the New World as "something less than serious science, akin to the ever popular search for 'Big Foot' or the 'Loch Ness Monster'" [58, p. 278]. As one of us has observed elsewhere, Martin's position has become a faith-based policy statement rather than a scientific statement about the past, an overkill credo rather than an overkill hypothesis [36,37].

By emphasizing the nature of the problem and by focusing research on the latest Pleistocene archaeology and paleontology of North America, Martin's arguments have led to a good deal of productive science. Now, however, it has become quite clear that things did not happen the way that Martin has envisaged. Martin's arguments drawn from islands are not relevant to continental settings, especially given that in every known instance, island extinctions were accompanied by massive habitat disruption. Northern Hemisphere mammal communities saw substantial extinctions at the end of the Pleistocene, with or without Clovis and even with or without a human presence. There are no kill sites for 26 of the 28 genera of North American herbivores and only 14 sites for the remaining two. It remains fully possible that the North American extinctions were not confined to the very end of this period, but were scattered across thousands of years, as occurred in Europe. Unless we can somehow accept that the very absence of evidence demonstrates that overkill occurred, it is time to focus on understanding what really did happen.

Unfortunately, what did happen is not at all clear. Although a number of climate-based hypotheses have been forwarded for North America [28,41], none have gained widespread acceptance, since none connect particular climate variables with particular organisms in powerful ways. Doing so is likely to be a daunting task, since it is very likely that an adequate explanation will have to be built by treating each organism on its own [27]. Nonetheless, experience in other parts of the world shows that it can be done $[18,40]$. It is clearly time to begin the task in a North American context.

\section{Acknowledgements}

Our thanks to Kristine M. Bovy for extremely valuable assistance with a draft of this manuscript, and to Carol J. Frey, Barbara E. Grayson, Richard G. Klein, Michael J. Shott, and David G. Anderson for help provided along the way.

\section{References}

[1] J. Alroy, A multispecies overkill simulation of the end-Pleistocene megafaunal mass extinction, Science 292 (2001) 1893-1896.

[2] J. Alroy, Did human hunting cause mass extinction? Science 294 (2001) 1459-1460.

[3] M.S. Alvard, Conservation by native peoples: prey choice in a depleted habitat, Human Nature 5 (1994) 127-154.

[4] M.S. Alvard, Indigenous hunting in the Neotropics: conservation or optimal foraging?, in: T. Caro (Ed.), Behavioral Ecology and Conservation Biology, Oxford University Press, New York, 1998, pp. $474-500$.

[5] A. Anderson, Prodigious Birds, Cambridge University Press, Cambridge, 1989.

[6] A. Anderson, Differential reliability of ${ }^{14} \mathrm{C}$ AMS ages of Rattus exulans bone gelatin in south Pacific prehistory, Journal of the Royal Society of New Zealand 30 (2000) 243-261.

[7] J. Baden (Ed.), Earth Day Reconsidered, The Heritage Foundation, Washington, DC, 1980.

[8] W. Balée, Indigenous transformation of Amazonian forests: an example from Maranhão, Brazil, L’Homme 33 (1993) 231-254.

[9] J. Blondel, J.-D. Vigne, Space, time, and man as determinants of diversity of birds and mammals in the Mediterranean region, in: R.E. Ricklefs, D. Schluter (Eds.), Species Diversity in Ecological Communities, University of Chicago Press, Chicago, 1993, pp. $135-146$.

[10] A. Bridault, L. Chaix, G. Pion, C. Oberlin, S. Thiébault, J. Argant, Position chronologique du renne (Rangifer tarandus L.) dans les Alpes de nord françaises et le Jura méridional, in: G. Pion (Dir.), Le Paléolithique supérieur recent: Nouvelles données sur le peuplement et l'environnement, Société Préhistorique Française Mémoire 28 (2000) 47-57.

[11] J.H. Brown, Macroecology, University of Chicago Press, Chicago, 1995

[12] J.H. Brown, W. McDonald, Livestock grazing and conservation on Southwestern rangelands, Conservation Biology 9 (1995) 1644-1647.

[13] R. Carson, Silent Spring, Houghton Mifflin, Boston, 1962.

[14] C.S. Churcher, P.W. Parmalee, G.L. Bell, J.P. Lamb, Caribou from the late Pleistocene of northwestern Alabama, Canadian Journal of Zoology 67 (1989) 1210-1216.

[15] C.J. Clausen, A.D. Cohen, C. Emiliani, J.A. Holman, J.J. Stipp, Little Salt Spring, Florida: a unique underwater site, Science 204 (1979) 609-614.

[16] A. Coard, A.T. Chamberlain, The nature and timing of faunal change in the British Isles across the Pleistocene/Holocene transition, The Holocene 9 (1999) 372-376.

[17] M. Culver, W.E. Johnson, J. Pecon-Slattery, S.J. O’Brien, Genomic ancestry of the American puma (Puma concolor), Journal of Heredity 91 (2000) 186-187.

[18] F. Delpech, Biomasse d'ongulés au Paléolithique et inférences démographiques, Paléo 11 (1999) 19-42.

[19] J.M. Diamond, Historic extinction: a Rosetta Stone for understanding prehistoric extinctions, in: P.S. Martin, R.G. Klein (Eds.), Quaternary Extinctions: A Prehistoric Revolution, University of Arizona Press, Tucson, 1984, pp. 824-862.

[20] J.M. Diamond, The mammoths' last migration, Nature 319 (1986) 265-266.

[21] J.M. Diamond, The present, past and future of human-caused extinctions, Royal Society of London Philosophical Transactions B 325 (1989) 469-477.

[22] J.M. Diamond, The Third Chimpanzee: The Evolution and Future of the Human Animal, Harper and Collins, New York, 1992.

[23] T.D. Dillehay, Monte Verde: a late Pleistocene settlement in Chile, The Archaeological Context and Interpretation vol. 2, Smithsonian Institution Press, Washington, DC, 1997. 
[24] J.S. Dunbar, S.D. Webb, Bone and ivory tools from submerged Paleoindian sites in Florida, in: D. Anderson, K. Sassaman (Eds.), The Paleoindian and Early Archaic Southeast, University of Alabama Press, Tuscaloosa, 1996, pp. 331-353.

[25] P.R. Ehrlich, The Population Bomb, Ballantine Books, New York, 1968.

[26] FAUNMAP Working Group, FAUNMAP: a database documenting late Quaternary distributions of mammal species in the United States, Illinois State Museum Scientific Papers 25 (1994).

[27] FAUNMAP Working Group, Spatial responses of mammals to late Quaternary environmental fluctuations, Science 272 (1996) 1601-1606.

[28] R.W. Graham, E.L. Lundelius Jr., Coevolutionary disequilibrium and Pleistocene extinctions, in: P.S. Martin, R.G. Klein (Eds.), Quaternary Extinctions: A Prehistoric Revolution, University of Arizona Press, Tucson, 1984, pp. 211-222.

[29] D.K. Grayson, The Establishment of Human Antiquity, Academic Press, New York, 1983.

[30] D.K. Grayson, Archaeological associations with extinct Pleistocene mammals in North America, Journal of Archaeological Science 11 (1984) 213-221.

[31] D.K. Grayson, Explaining Pleistocene extinctions: thoughts on the structure of a debate, in: P.S. Martin, R.G. Klein (Eds.), Quaternary Extinctions: A Prehistoric Revolution, University of Arizona Press, Tucson, 1984, pp. 807-823.

[32] D.K. Grayson, Nineteenth-century explanations of Pleistocene extinctions: a review and analysis, in: P.S. Martin, R.G. Klein (Eds.), Quaternary Extinctions: A Prehistoric Revolution, University of Arizona Press, Tucson, 1984, pp. 5-39.

[33] D.K. Grayson, Perspectives on the archaeology of the first Americans, in: R.L. Carlisle (Ed.), Ice Age Origins: Americans Before Columbus, Ethnology Monographs vol. 12, 1988, pp. 107-123.

[34] D.K. Grayson, Late Pleistocene extinctions in North America: taxonomy, chronology, and explanations, Journal of World Prehistory 5 (1991) 193-232.

[35] D.K. Grayson, Did human hunting cause mass extinction? Science 294 (2001) 1459.

[36] D.K. Grayson, The archaeological record of human impacts on animal populations, Journal of World Prehistory 15 (2001) 1-68.

[37] D.K. Grayson, Reassessing overkill: early Americans and Pleistocene mammals, in: C.M. Porter (Ed.), Zooarchaeology: Papers in Honor of Elizabeth S. Wing, Bulletin of the Florida State Museum of Natural History 29 (2002) 1439-1449.

[38] D.K. Grayson, F. Delpech, Specialized early Upper Paleolithic hunters in southwestern France? Journal of Archaeological Science, 2002, in press.

[39] D.K. Grayson, D.J. Meltzer, The human colonization of North America, Clovis hunting and large mammal extinction, unpublished manuscript, 2002.

[40] D.K. Grayson, F. Delpech, J.-Ph. Rigaud, J. Simek, Explaining the development of dietary dominance by a single ungulate taxon at Grotte XVI, Dordogne, France, Journal of Archaeological Science 28 (2001) 115-125.

[41] R.D. Guthrie, Mosaics, allelochemics, and nutrients: an ecological theory of late Pleistocene megafaunal extinctions, in: P.S. Martin, R.G. Klein (Eds.), Quaternary Extinctions: A Prehistoric Revolution, University of Arizona Press, Tucson, 1984, pp. 259-298.

[42] J.J. Hester, The agency of man in animal extinctions, in: P.S. Martin, H.E. Wright Jr. (Eds.), Pleistocene Extinctions: The Search for a Cause, Yale University Press, New Haven, 1967, pp. 169-192.

[43] R.N. Holdaway, New Zealand's pre-human avifauna and its vulnerability, New Zealand Journal of Ecology 12 (Suppl.) (1989) $11-25$.
[44] R.N. Holdaway, A spatio-temporal model for the invasion of the New Zealand archipelago by the Pacific rat Rattus exulans, Journal of the Royal Society of New Zealand 29 (1999) 91-105.

[45] R.N. Holdaway, Introduced predators and avifaunal extinction in New Zealand, in: R.D.E. MacPhee (Ed.), Extinctions in Near Time, Kluwer Academic/Plenum Publishers, New York, 1999, pp. 189-238.

[46] J.A. Holman, C.J. Clausen, Fossil vertebrates associated with Paleo-Indian artifacts at Little Salt Spring, Florida, Journal of Vertebrate Paleontology 4 (1984) 146-154.

[47] P.V. Kirch, Changing landscapes and sociopolitical evolution in Mangaia, central Polynesia, in: P.V. Kirch, T.L. Hunt (Eds.), Historical Ecology in the Pacific Islands: Prehistoric Environmental and Landscape Change, Yale University Press, New Haven, 1997, pp. 147-165.

[48] P.V. Kirch, Microcosmic histories: island perspectives on "global" change, American Anthropologist 99 (1997) 30-42.

[49] P.V. Kirch, D.W. Steadman, V.L. Butler, J. Hather, M.I. Weisler, Prehistory and human ecology at Tangatatau Rockshelter, Mangaia, Cook Islands, Archaeology in Oceania 30 (1995) 47-65.

[50] R.H. MacArthur, E.O. Wilson, The Theory of Island Biogeography, Princeton University Press, Princeton, 1967.

[51] R.D.E. MacPhee, A.N. Tikhonov, D. Mol, C. de Marliave, H. van der Plicht, A.D. Greenwood, C. Flemming, L. Agenbroad, Radiocarbon chronologies and extinction dynamics of late Quaternary mammalian megafauna from the Taimyr Peninsiula, Russian Federation, Journal of Archaeological Science 29 (2002) 1017-1042.

[52] P.S. Martin, Pleistocene ecology and biogeography of North America, in: C.L. Hubbs (Ed.), Zoogeography, American Association for the Advancement of Science, Washington, DC, 1958, pp. 375-420.

[53] P.S. Martin, The Last 10,000 Years: A Fossil Pollen Record of the American Southwest, University of Arizona Press, Tucson, 1963.

[54] P.S. Martin, Prehistoric overkill, in: P.S. Martin, H.E. Wright Jr. (Eds.), Pleistocene Extinctions: The search for a Cause, Yale University Press, New Haven, 1967, pp. 75-120.

[55] P.S. Martin, The discovery of America, Science 179 (1973) 969-974.

[56] P.S. Martin, Prehistoric overkill: the global model, in: P.S. Martin, R.G. Klein (Eds.), Quaternary Extinctions: A Prehistoric Revolution, University of Arizona Press, Tucson, 1984, pp. 354-403.

[57] P.S. Martin, Who or what destroyed our mammoths? in: L.D. Agenbroad, J.I. Mead, L.W. Nelson (Eds.), Megafauna and Man: Discovery of America's Heartland, Hot Springs, The Mammoth Site of Hot Springs, South Dakota, 1990, pp. 109-117.

[58] P.S. Martin, Deep history and a wilder west, in: R.H. Robichaux (Ed.), Ecology of Sonoran Desert Plants, University of Arizona Press, Tucson, 1999, pp. 256-290.

[59] P.S. Martin, D.W. Steadman, Prehistoric extinctions on islands and continents, in: R.D.E. MacPhee (Ed.), Extinctions in Near Time, Kluwer Academic/Plenum Publishers, New York, 1999, pp. 17-52.

[60] P.S. Martin, R.S. Thompson, R. Long, Shasta ground sloth extinction: a test of the blitzkrieg model, in: J.I. Mead, D.J. Meltzer (Eds.), Environments and Extinctions: Man in Late Glacial North America, Center for the Study of Early Man, University of Maine, Orono, 1985, pp. 5-14.

[61] H.G. McDonald, The late Pleistocene vertebrate fauna in Ohio: coinhabitants with Ohio's Paleoindians, in: W.S. Dancey (Ed.), The First Discovery of America: Archaeological Evidence of the Early Inhabitants of the Ohio Area, The Ohio Archaeological Council, Columbus, 1994, pp. 23-39.

[62] M.S. McGlone, Polynesian deforestation of New Zealand: a preliminary synthesis, Archaeology in Oceania 18 (1983) 11-25. 
[63] M.S. McGlone, The Polynesian settlement of New Zealand in relation to environmental and biotic changes, New Zealand Journal of Ecology 12 (Suppl.) (1989) 115-129.

[64] M.S. McGlone, J.M. Wilmshurst, Dating initial Maori environmental impact in New Zealand, Quaternary International 59 (1999) 5-16.

[65] J.I. Mead, P.S. Martin, R.C. Euler, A. Long, A.J.T. Jull, L.J. Toolin, D.J. Donahue, T.W. Linick, Extinction of Harrington's mountain goat, Proceedings of the National Academy of Sciences of the United States of America 83 (1986) 836-839.

[66] D.J. Meltzer, The antiquity of man and the development of American archaeology, Advances in Archaeological Method and Theory 6 (1983) 1-51.

[67] D.J. Meltzer, Why don't we know when the first people came to North America? American Antiquity 54 (1989) 471-490.

[68] D.J. Meltzer, Monte Verde and the Pleistocene peopling of the Americas, Science 276 (1997) 754-755.

[69] D.J. Meltzer, D.K. Grayson, G. Ardila, A.W. Barker, D.F. Dincauze, C.V. Haynes, F. Mena, L. Nunez, D.J. Stanford, On the Pleistocene antiquity of Monte Verde, southern Chile, American Antiquity 62 (1997) 659-663.

[70] M. Menotti-Raymond, S.J. O'Brien, Dating the genetic bottleneck of the African cheetah, Proceedings of the National Academy of Sciences of the United States of America 90 (1993) 3172-3176.

[71] G.S. Morgan, C.A. Woods, Extinction and the zoogeography of West Indian land mammals, Biological Journal of the Linnaean Society 28 (1986) 167-203.

[72] J.E. Mosimann, P.S. Martin, Simulating overkill by Paleoindians, American Scientist 63 (1975) 304-313.

[73] S.L. Olson, H.F. James, Fossil birds from the Hawaiian Islands: evidence for wholesale extinction by man before Western contact, Science 217 (1982) 633-635.

[74] S.L. Olson, H.F. James, Prodromus of the fossil avifauna of the Hawaiian Islands, Smithsonian Contributions to Zoology 365 (1982).

[75] S.L. Olson, H.F. James, The role of Polynesians in the extinction of the avifauna of the Hawaiian Islands, in: P.S. Martin, R.G. Klein (Eds.), Quaternary Extinctions: A Prehistoric Revolution, University of Arizona Press, Tucson, 1984, pp. 768-780.

[76] G. Paulay, Biodiversity on oceanic islands: its origin and extinction, American Zoologist 34 (1994) 134-144.

[77] S. Pimm, Cenozoic dramas, Science 292 (2001) 1841-1842.

[78] E.A. Powell, Curtains for overkill? Archaeology 55 (1) (2001) $16-17$.
[79] M.L. Rosenzweig, Species Diversity in Space and Time, Cambridge University Press, Cambridge, 1995.

[80] T.M. Smith, T.R. Karl, R.W. Reynolds, How accurate are climate simulations?, Science 296 (2002) 483-484.

[81] D.W. Steadman, Fossil birds from Mangaia, southern Cook Islands, British Ornithological Union Bulletin 105 (1985) 48-66.

[82] D.W. Steadman, Extinction of birds in eastern Polynesia: a review of the record, and comparisons with other Pacific Island groups, Journal of Archaeological Science 6 (1989) 177-205.

[83] D.W. Steadman, P.V. Kirch, Prehistoric extinction of birds on Mangaia, Cook Islands, Polynesia, Proceedings of the National Academy of Sciences of the United States of America 87 (1990) 9605-9609.

[84] D.W. Steadman, S.L. Olson, Bird remains from an archaeological site on Henderson Island, South Pacific: man-caused extinctions on an "uninhabited" island, Proceedings of the National Academy of Sciences of the United States of America 82 (1985) 6191-6195.

[85] A.J. Stuart, Late Pleistocene megafaunal extinctions: a European perspective, in: R.D.E. MacPhee (Ed.), Extinctions in Near Time, Kluwer Academic/Plenum Publishers, New York, 1999, pp. 257-269.

[86] R.E. Taylor, Ahead of the Curve: Shaping New Solutions to Environmental Problems, Environmental Defense Fund, New York, 1989.

[87] J.-D. Vigne, L'extinction holocène du fond de peuplement mammalien indigène des îles de Méditerranée occidentale, Société Géologique de France Mémoire 150 (1987) 167-177.

[88] P.D. Ward, Rivers in Time: The Search for Clues to Earth's Mass Extinctions, Columbia University Press, New York, 2000.

[89] T. Webb III (Ed.), Late Quaternary Climates: Data Synthesis and Model Experiments, Quaternary Science Reviews (1998) 465-688.

[90] S.V. Wood Jr., On the climate of the post-glacial period, Geological Magazine 10 (1872) 153-161.

[91] P. Woodman, M. McCarthy, N. Monaghan, The Irish Quaternary fauna project, Quaternary Science Reviews 16 (1997) 129-159.

[92] C.A. Woods, The biogeography of West Indian rodents, in: C.A. Woods (Ed.), Biogeography of the West Indies: Past, Present, and Future, Sandhill Crane Press, Gainesville, 1989, pp. 741-798.

[93] T.H. Worthy, R.N. Holdaway, The Lost World of the Moa: Prehistoric Life of New Zealand University of Indiana Press, Bloomington, 2002. 